\title{
Synergy between behavioural research on beluga whales (Delphinapterus leucas) conducted in zoological and wild settings
}

\author{
Heather M. Manitzas Hill'1 , Deirdre B. Yeater² \& Michael Noonan³ \\ 'Psychology Department, St. Mary's University, San Antonio, TX, USA; \\ ${ }^{2}$ Psychology Department, Sacred Heart University, Fairfield, CT, USA; \\ ${ }^{3}$ Biology Department, Canisius College, Buffalo, NY, USA
}

\begin{abstract}
Behavioural observations of captive beluga whales have complemented and extended much of what has been learnt about this species in the wild. Aquarium-based research has provided finer-scale specificity for many topics, including the seasonal breeding pattern that is characteristic of this species, as well as socio-sexual behaviour that appears to be an important part of the behavioural repertoire of this species. One example is a strong propensity for male-male social interactions that begin to develop at an early age. In addition, detailed behavioural milestones in calves have been documented in ways that extend that which have been collected from wild populations. These include swim positions with mother, separations/reunions with mother, and other social interactions, and play. Characteristics of beluga maternal care have also been studied more often in captive settings than in the wild, particularly with respect to details pertaining to nursing behaviour, individual differences in maternal style and allomaternal care. Other topics that have received scientific scrutiny in zoological settings include individual differences and behavioural laterality. Thus, a greater understanding of beluga behavioural biology has the potential to emerge as a consequence of synergy between research conducted in the two settings.
\end{abstract}

This article is part of the special cluster Beluga whales (Delphinapterus leucas): knowledge from the wild, human care and TEK, which has been funded by Mystic Aquarium, CAFF and the Norwegian Ministry of Climate and Environment.

\section{Introduction}

The beluga or white whale (Delphinapterus leucas) is a gregarious species that is observed throughout the sub-Arctic/ Arctic region (Brodie 1971; Sergeant 1973; Boltunov \& Belikov 2002; Loseto et al. 2006; Chernetsky et al. 2011; Krasnova et al. 2012; Colbeck et al. 2013). While continuing to be important to subsistence hunters, belugas are now also considered to be a sentinel species for the overall health of the polar region (Huntington et al. 1999; Mymrin et al. 1999). As a consequence, the monitoring of beluga populations with regard to their migrations, foraging, calving and social interactions has become a critical activity for many governments and researchers. Unfortunately, the remote and challenging nature of their natural habitat has limited most wild-based research to population counts, migration patterns and short-term behavioural observations that will be integrated throughout this review (e.g., Brodie 1971; Sergeant 1973; Heide-Jørgenson \& Teilmann 1994; O'CorryCrowe et al. 1997; Boltunov \& Belikov 2002; Michaud 2005; Loseto et al. 2006; Chernetsky et al. 2011; Krasnova et al. 2012; Colbeck et al. 2013; O'Corry-Crowe et al. 2020).

Although belugas in zoological facilities are unable to express some portions of their behavioural repertoire (e.g., foraging and migrations), conducting research in such facilities offers a number of advantages. These advantages include (1) far greater accessibility of the animals, (2) greater visibility that allows the observation of critical details, like sequence of behaviours, initiators, receivers, body orientations, postures, eye directions, etc., and (3) the ability to follow individuals over long time frames to evaluate seasonal and life-span developmental changes. The purpose of this 
article is to review the behavioural research that has been conducted on belugas in zoological facilities, and to articulate the ways in which such research has complemented and extended that which has been learnt in the wild.

\section{Social structure/affiliative behaviour}

In the wild, beluga social structure is often inferred to be a fission-fusion society in which individuals move into and out of each other's company (i.e., Godde et al. 2013). This inference has been driven by the tendency of most beluga populations to congregate in large mixed sex and age herds during summers, while at other times groups are observed that are comprised solely of adult males, solely of juveniles and loose association of mothers with calves (Brodie 1971; Sergeant 1973; Heide-Jørgenson \& Teilmann 1994; O'CorryCrowe et al. 1997; Boltunov \& Belikov 2002; Michaud 2005; Loseto et al. 2006; May-Collado et al. 2007; Chernetsky et al. 2011; Krasnova et al. 2012; Colbeck et al. 2013).

Most previous works on wild beluga populations have consisted of information about the size of social groupings, distribution movements, foraging and anecdotal information regarding affiliative interactions (Brodie 1971; Sergeant 1973; Heide-Jørgenson \& Teilmann 1994; O'Corry-Crowe et al. 1997; Boltunov \& Belikov 2002; Michaud 2005; Loseto et al. 2006; May-Collado et al. 2007; Chernetsky et al. 2011; Krasnova et al. 2012; Colbeck et al. 2013). Due to constraints of access and technology most studies with wild populations have focused on surface-based behaviour. More recently, with advances in technology, genetic evidence is elucidating the relationships between beluga social groups in over 10 different populations around the globe, indicating that both kin and non-kin individuals are observed together in various social groups (O'Corry-Crowe et al. 2020).

By contrast, research in zoological institutions has provided much greater specificity. Findings have included that male-male dyads are much more common than female-female dyads regardless of age (Hill, Garcia de Oliveira Silva-Gruber et al. 2018; Mazikowski et al. 2018). In one zoological population that included six males and 15 females, male-male adult dyads interacted at rates seven times that of female-female adult dyads (Hill, Garcia de Oliveira Silva-Gruber et al. 2018). This pattern was recently replicated by research conducted at a second zoological facility consisting of five males and five females, which also demonstrated a seasonality effect (Ham et al. 2021 [this special cluster]). Male-male calf dyads, across two different zoological facilities, occurred almost four times more often than female-female calf dyads (Mazikowski et al. 2018). Mixed sex adult dyads and mixed sex calf dyads occurred but much less frequently (Hill, Garcia de Oliveira Silva-Gruber et al. 2018;
Mazikowski et al. 2018). These patterns of affiliative swim associations based on proximity make it clear that male belugas prefer to spend time with male belugas as compared to female belugas, and that this preference appears to begin relatively early in development, emerging within the first three years of life (Mazikowski et al. 2018).

\section{Tactile behaviour}

Behavioural observations of wild belugas have shown that when they swim in close proximity to one another, they often contact one another (Huntington 2005; Michaud 2005; Alekseeva et al. 2013; Krasnova et al. 2014). These observations have occurred primarily in shallow waters where large beluga congregations occur (e.g., Cunningham Inlet, G. Freund, pers. comm., 2020). Large white belugas, presumably males, have also been reported to both congregate together and display contact behaviour during seemingly affiliative interactions (Alekseeva et al. 2013), and calves have been observed contacting each other and other larger belugas (Krasnova et al. 2009; Alekseeva et al. 2013; Karenina et al. 2013; Krasnova et al. 2014).

When such tactile contact was assessed for a captive population of eight belugas using surface-based observations over an entire year, tactile contact between calves was frequent, while tactile contact between adult females was found to almost never occur (tactile contact between adult males could not be assessed [Hill, Alvarez et al. 2016]). Similar trends were replicated when mother-calf dyads were examined using underwater video footage (Hill, Dietrich et al. 2018). More recently, an assessment of tactile contact among 47 belugas housed in larger social groupings have produced similar findings (unpublished data). In addition, evidence from a small number of beluga calves indicated that social interactions lasted longer when tactile contact occurred than when it did not (Hill, Dietrich et al. 2018). In all, these results suggest that the frequency of tactile contact between belugas is significantly influenced by age and sex. Finally, the overall rates of contact are lower than what has been observed for delphinids in both zoological and wild settings (Dudzinski et al. 2009; Dudzinski et al. 2010; Dudzinski \& Ribic 2017).

Follow-up studies underway by the present authors are exploring the distinction between proximity and contact as indices of sociality in belugas, and preliminary results suggest that very different roles may be played by interindividual physical closeness versus inter-individual touching in males versus females. Additional investigations into the role of tactile contact during affiliative interactions will be critical for elucidating the function of touching in social behaviour. In most animal species, tactile contact is critical as a means by which to mediate relationships between 
individuals within a society (Tamaki et al. 2006; Dudzinski \& Ribic 2017; Themelin et al. 2020), especially when the social structure is fission-fusion in nature as seems to be the case for most delphinids and perhaps for belugas.

\section{Socio-sexual interactions}

Socio-sexual interactions are non-conceptive social behaviours in which the genital region can be targeted but may also include a number of other behaviours that are adopted from sexual, conceptive contexts (Furuichi et al. 2014). Across multiple species, these interactions typically involve same-sex dyads or groups, but in cetaceans, such as delphinids, they can involve mixed sexes and ages (Mann 2006; Connor \& Krutzen 2015). Socio-sexual interactions are thought to fulfil several functions, including practice for future reproductive sexual behaviour, development and maintenance of bonds, dominance and reconciliation, and may represent an exaptation of reproductive behaviour (Vasey 1995). To date, socio-sexual behaviours by wild belugas have only been reported anecdotally (Michaud 2005; Alekseeva et al. 2013). The best example of socio-sexual behaviour in the wild is depicted in a series of aerial photographs captured during transect flyovers of the Cook Inlet, Alaska, beluga population. Several pairings of large white whales were observed in lateral presentations and side-byside swims with various 'S' postures (Lomac-MacNair et al. 2015). Images like these are valuable, but they are missing critical information, such as the sex and age of the dyad members. Without information about the individuals, the context and/or function are speculative at best.

By contrast, in zoological facilities these kinds of social interactions can be studied year-round, assuming the social groupings are appropriate to elicit the behaviours of interest. Data collected from three different US-based zoological facilities demonstrated that socio-sexual behaviours were more likely to occur between adult-sub-adult male dyads, adult-male-juvenile dyads and calf-calf or juvenile-juvenile dyads (Hill, Dietrich et al. 2015). Reciprocated, lateral swims, extended pectoral fins, bubble trails, 'S' postures with the genital region pushed forward and pelvic thrusts are common socio-sexual behaviours (see figure 1 in Hill, Dietrich et al. 2015), with pelvic thrusts and mouthing having the greatest opportunity for tactile contact. In calves studied at one facility, socio-sexual behaviour did not clearly emerge until about three years of age, the age also associated with first observation of calf erections (Hill, Dietrich et al. 2015). Thus, some socio-sexual behaviours, such as genital rubs and genital contact, occur early in belugas but not as frequently as seen in bottlenose dolphins (Kuczaj et al. 2006; Mann 2006). More recent work on the development of socio-sexual behaviours beyond the calf stage has shown how the behaviours become more organized with age (Lilley et al. 2020). Additionally, seasonal variation in socio-sexual behaviour becomes more predictable as the calves age into sub-adults and adults (Ham et al. 2021 [this special cluster]). Female belugas do not seem to engage in socio-sexual interactions once sexually mature (Glabicky et al. 2010; Hill, Dietrich et al. 2015), but they will engage in socio-sexual behaviours and interactions as calves, despite not displaying all behaviours within the socio-sexual repertoire (Hill, Dietrich et al. 2015; Lilley et al. 2020).

Developmental work conducted across several facilities has demonstrated the importance of male-male bonds and mixed age and sex social groupings to both facilitate the expression of the behavioural repertoire and diversify behaviours (Hill \& Ramirez 2014; Hill, Guarino et al. 2015; Hill, Garcia de Oliveira Silva-Gruber et al. 2018; Mazikowski et al. 2018; Lilley et al. 2020). Preliminary evidence from an ongoing study by the present authors documenting tactile contact in 47 belugas housed at one facility supports this impression as female calves rarely experienced direct genital contact or initiated genital contact, despite receiving genital contact on other parts of their bodies. Clearly, more research is needed to clarify the function of socio-sexual interactions, as is also the case for most cetacean species (Bailey \& Zuk 2009).

\section{Courtship and reproductive interactions}

The courtship and reproductive behaviours of belugas have also not been systematically studied in any wild beluga population. While mixed sex social groupings have been reported, mating attempts and courtship behaviours have only been occasionally observed (Chernetsky et al. 2011; Krasnova et al. 2012; Alekseeva et al. 2013). Studying these behaviours in the wild from surface-based observations is challenging as it requires clear, calm water, identified individuals and the ability to follow the behaviour sequence for each interactant. Michaud, a prominent beluga expert, wrote that after more than 20 years of boat time and thousands of surface observations, he had only observed only "five mating attempts, one possible birth, no nursing" (2005: 303).

In the wild, mating seasons have been estimated from physiological evidence (testis size or foetal age from deceased animals), estimated calf age during population counts, and traditional knowledge shared by subsistence hunters (e.g., Huntington et al. 1999; Mymrin et al. 1999; Chernetsky et al. 2011; Krasnova et al. 2012; Alekseeva et al. 2013; Shelden et al. 2019). Based on this aggregated knowledge, it is clear that belugas are seasonal breeders, with peak breeding season estimated to fall between March and June (Huntington et al. 1999; Chernetsky et al. 2011; Krasnova et al. 2012; Alekseeva et al. 2013; Shelden et al. 2019). 
Research conducted with belugas at several different zoological facilities has also documented a seasonal increase in male-female interactions that corresponds to a breeding season. Glabicky et al. (2010) documented that male-to-female genital thrusts peaked in frequency in March, with reductions to near-zero levels following the end of the breeding season. These seasonal interactions have been corroborated with increases in reproductive hormones for both sexes (Robeck et al. 2005; Richard et al. 2021 [this special cluster]).

Details of the behavioural components of courtship were first described by Recchia (1994) in her dissertation on the social behaviour of belugas at several different facilities and included into an interactive computer-based ethogram constructed for another facility (DiPaola et al. 2007). An even more detailed catalogue of courtship, reproduction, socio-sexual and agonistic behaviours was created from multiple sources of information including previous papers and personal observations (Hill, Dietrich et al. 2015). Many of the behaviours observed overlapped different social behaviour categories. However, the context did elicit subtle differences in topographies. For example, males (and females) often display ' $S$ ' postures that can either be held briefly while stationary in the water or dynamically moved through in transition to a pelvic thrust (Hill, Dietrich et al. 2015; Lilley et al. 2020). However, an important insight gained from such captivity-based research is that, depending on the position of the pelvic region, the ' $S$ ' posture can be a sign of courtship, socio-sexual behaviour or agonism (Horback et al. 2010; Hill, Dietrich et al. 2015). Other behaviours that appear to be part of the male courtship repertoire are directed gazes, following, synchronous swims in close proximity to the female, bubble trails and perhaps mouthing (Hill, Dietrich et al. 2015).

Subsequent studies, some of which are in progress, are expanding our understanding of beluga courtship by (1) investigating a suspected diel rhythm in mating behaviour, (2) detailing the specific sequence in which such behaviours typically occur, (3) uncovering how such behaviours vary as a function of group size and composition, and (4) identifying the complementary roles played by the two sexes. Preliminary indications are that it is common for more than one male to approach a potentially receptive female in an apparently cooperative fashion, and that the female plays a significant role in determining which of the males ultimately achieves copulation. This topic represents a gap in knowledge that is particularly relevant for the conservation of depleted wild populations (e.g., Cook Inlet, Alaska, and St. Lawrence, Quebec).

\section{Mother-calf interactions}

Research conducted in the wild has documented preferred habitats for mothers and calves (e.g., Huntington et al. 1999; Mymrin et al. 1999; Chernetsky et al. 2011; McGuire et al. 2020). Beyond that, most of the available knowledge about interactions between beluga mothers and calves in wild populations has been derived from the beluga population found in the White Sea, where research has been ongoing every summer since the mid1990s (Krasnova et al. 2006, 2009; Krasnova et al. 2014). In this population, beluga mothers and their calves maintain their association for an average of two years and older, weaned offspring remain with the natal group. Reported interactions between mother belugas and their calves have included separations, reunions, species-specific, age-specific and lateralized swim positions, nursing, play, affiliative contact and the disciplining of the calf (Krasnova et al. 2003; Krasnova et al. 2006; Karenina et al. 2010; Karenina et al. 2013; Krasnova et al. 2014). Beluga calves appear to show early independence from their mothers, separating and interacting with other calves or other females within two months of life (Krasnova et al. 2014). This early autonomy may be mediated by contact calls that appear to contain information about individual identity (Vergara et al. 2010; Vergara \& Mikus 2019). The emergence of similarly early independence has been reported for Cook Inlet belugas ( $\mathrm{T}$. McGuire, pers comm.). Interestingly, while mothers and calves tend to be segregated from adult males in the White Sea (Krasnova et al. 2009; Krasnova et al. 2014), mothers and calves are often found in mixed sex and age social groupings in Cook Inlet (McGuire et al. 2020).

The opportunity to closely observe mothers and their calves through underwater windows is unique to zoological facilities, and it offers unparalleled opportunities that even the best conditions in the wild cannot match. Aquarium-based work that is ongoing by the authors indicates that it is common for a parturient female to distance herself from other whales during most of her labour. As the time of birth gets close, other adult females characteristically swim very close to her, and it is they who usually first push the neonate to the surface when it is delivered. Details about this perinatal behaviour are forthcoming.

Maternal behaviours such as disciplining the calf, intervening in its activity and calf monitoring activities have suggested consistent individual differences in maternal styles (Hill 2009; Hill et al. 2013). Contact between mothers and calves, which is mostly initiated by calves, appears to facilitate the development of their bond (Hill, Dietrich et al. 2018). Additionally, recent preliminary analysis of 21 mother-calf pairs has suggested that mothers may have varying rates of initiation of contact with 
their calves. This information may clarify differences in maternal style and long-term outcomes of calf success.

\section{Allomothering}

The apparent care of young belugas by other belugas that are not their mothers has been reported in several wild populations (e.g., Krasnova et al. 2014). Although such reports have only been anecdotal and the observations fleeting, they raise the possibility that allocare may be a normal part of the beluga behavioural repertoire. As a possible confirmation of that, one zoology-based study found that allocare interactions occurred for several calves when sub-adult or adult nulliparous females were available (Hill \& Campbell 2014). Until researchers can differentiate biological mothers in the wild from allomothers few conclusions can be drawn from these observations.

\section{Developmental landmarks}

The importance of fully understanding the behavioural development of beluga calves was illustrated by the challenges faced when a very young beluga calf live-stranded in 2017 near the town of Tyonek, Alaska, and local officials assessed the prospects for the stranded calf (Shelden et al. 2019). Despite the fact that numerous stocks of wild belugas had been monitored for years, there were very little specific data stemming from wild populations about developmental landmarks against which to compare the status of the stranded calf.

Fortunately, however, there was already a great deal of pertinent information stemming from research in captivity. Behavioural developmental milestones, such as initiation of separations, initiation of reunions, swim positions, nursing, play, social interactions, motor development, attention to environment and vocal development, had all been established (Vergara \& Barrett-Lennard 2008; Hill 2009; Leung et al. 2010; Hill et al. 2013; Hill \& Campbell 2014; Brown 2018; Ames \& Vergara 2020). As a result, an ad hoc consortium of personnel with expertise from wild and zoological settings was able to craft a successful rescue/rehabilitation programme (Goertz et al. 2019).

This case study was a particularly good example of the kind of synergy that is possible between wildlife researchers and those studying belugas in zoological facilities. In this regard, it should be noted that even more recently complementary findings have been obtained via very important longitudinal work that has been conducted on calves in the critically endangered beluga population of Cook Inlet (McGuire et al. 2020). Researchers from both areas should continue to collaborate on these types of studies.

\section{Play behaviour}

Play is important for both cognitive and social development in many social species, and cetacean species of all ages have been reported to play (Paulos et al. 2010; Hill et al. 2017). Consistent with this generalization, Krasnova et al. (2009) reported that White Sea beluga calves engaged in locomotor play and imitation of older juveniles. One specific example reported anecdotally by Krasnova et al. (2014) included two juvenile belugas in the White Sea engaging in a mouth-to-mouth interaction.

More detailed studies in captivity have expanded upon those observations and add to the growing evidence for certain types of social play, such as mouth-to-mouth social play (Hill, Dietrich et al. 2019). Hill \& Ramirez (2014) demonstrated that in addition to calves and juveniles, adult belugas also engaged in play behaviours; males engaged in more play bouts and a higher percentage of locomotor play activities. Hill, Guarino et al. (2015) found that young belugas interacting with adults lead to a greater diversity of behaviours.

\section{Direction and duration of gaze}

Borrowing a technique that has long been employed in the study of human babies (e.g., Baillargeon et al. 2015), animal researchers have been tracking the direction and duration of gaze as windows into the perceptual abilities and selective attention of their animal subjects. Along these lines, Karenina et al. (2010) found that wild belugas tend to view novel objects for longer periods than familiar objects. Similarly, they exhibited longer gaze durations when viewing unfamiliar people.

In an extension to that study in captivity, Hill, Yeater et al. (2016) also found that belugas looked longer at unfamiliar humans, regardless of their clothing (standardized or uniforms). The captive belugas also exhibited a longer gaze duration for active humans rather than stationary ones. Guarino et al. (2017) and Yeater et al. (2017) further confirmed that unfamiliar objects elicited longer gaze durations than familiar ones. Even more recently, individual differences were found in gaze length when both classes of stimuli, humans and objects, were combined and presented using a violation of expectation paradigm with an 'unexpected' change in stimuli (Halter, Yeater \& Manitzas Hill, unpubl. ms).

\section{Laterality}

In the wild, beluga calves were observed demonstrating a left-eye bias while maintaining social contact with their mothers (Karenina et al. 2013). In addition, wild belugas 
were found to view novel objects underwater more often using their left eye (Karenina et al. 2010). Both of these findings suggest a hemispheric asymmetry in belugas.

That inference that has been supported by follow-up studies conducted in captivity. When studying 12 belugas across multiple zoological facilities both Yeater et al. (2014) and Hill, Yeater et al. (2016) found lateralized eye preferences at the individual level. In an extension of this line of research, Guarino et al. (2017) and Yeater et al. (2017) found that belugas tended to view both familiar and novel objects using both eyes, but that they demonstrated a left eye preference when monocular vision was used. In combination, these findings suggest a right hemisphere (left eye) specialization for visual processing of object and social stimuli.

\section{Individual differences/behavioural syndromes}

In important ways, variations among individuals within a population provide the fuel that drives the engine of natural selection. A complete understanding of belugas must therefore also include the study of individual differences. Some have suggested that personality-based responses to various anthropogenic events (e.g., boats, pile-driving and presence of humans) or novel stimuli provided experimentally by researchers (e.g., Siniscalchi et al. 2012) can be evaluated in the wild (e.g., Highfill \& Kuczaj 2010). Unfortunately, to our knowledge, these studies have not yet made it to the peer-reviewed literature (e.g., Skrzypczak 2016). At the Second International Workshop on Beluga Whale Research and Conservation held at Mystic Aquarium, Mystic, Connecticut, USA, in March 2019, an observation was shared that some belugas had been recaptured more often than others during sensor-placement tagging events, which led to some discussion about the role of personality in those repeated tagging events (H.M. Manitzas Hill, pers. obs.). Similarly, anecdotes have been shared about free-ranging belugas that suggest individual variation in the degree of maternal permissiveness and attention (T. McGuire, pers. comm.).

These speculations notwithstanding, consistent behavioural/personality ratings require frequent observations of the same individual, a requirement that is rarely achievable in the wild. In addition, care must be taken to avoid biasing data as bolder, more neophilic or naive animals may be more likely to be observable while more timid, neophobic or experienced animals may be less likely to be observable (Richard et al. 2001).

A major advance on this topic was achieved in a recent study that was conducted on 41 captive belugas of mixed sex and age. Stable individual differences were found for 19 of 23 separate measures. These measures included 10 characteristics rated by trainers, and 13 spontaneous behaviours assessed by trained observers. Inter-rater and inter-time reliability were consistent and moderately strong, suggesting that belugas exhibit stable individual differences in various aspects of their behaviour that can be detected reliably across raters and over time, and a pattern of cross-trait correlation suggested the possibility that behavioural dispositions may cluster in ways that constitute behavioural syndromes (Hill, Woodruff et al. 2019).

Additionally, beluga play behaviour and maternal care have received some attention in terms of individual differences in belugas in zoological facilities (Hill et al. 2013; Hill, Guarino et al. 2015). Preferences of play behaviours and frequency of play emerged for a socially dynamic population at a US facility (Hill, Guarino et al. 2015), where variations in maternal care behaviours were also documented (Hill et al. 2013). Following this, Brown (2018) explored the development of temperament in seven calves from birth to two years by examining 40 different spontaneous behaviours. The findings indicated that a five-factor model was the best solution, which included mother-calf bond, sociability, independence, exploration-vigilance and curiosity-playfulness.

\section{Cognitive processes}

One advantage of aquarium-based settings is that it offers researchers the ability to manipulate variables in experimental studies under controlled conditions. This allows more precise conclusions to be drawn than those possible from studies that are solely observational. This is a particularly important factor in cognitive studies.

In one example of this kind of experiment, a captive beluga 'labelled' objects by matching a sample sounds with objects (Tsukasa et al. 2012). Murayama et al. (2017) found this same beluga also passed a test of transitivity. Moreover, the beluga was able to identify the symmetrical relations across modalities (visual and auditory). In other work, Abramson et al. (2013) demonstrated that a beluga could make relative quantity judgements by choosing a larger quantity above chance levels. Additional studies underway by the present authors include experiments on social learning, tool use, creativity and executive functioning during information processing.

\section{Discussion}

As this review shows, belugas in aquariums exhibit many behaviours that match those observed in their wild counterparts. It is also clear that, because of the greater opportunities for sustained observations, investigations conducted in zoological institutions can help 
Table 1 Behavioural characteristics of beluga whales: comparison of observations obtained in the wild and observations obtained in zoological facilities.

\begin{tabular}{|c|c|c|c|c|c|}
\hline & $\begin{array}{l}\text { Observations obtained } \\
\text { from the wild }\end{array}$ & $\begin{array}{l}\text { Key references from } \\
\text { the wild }\end{array}$ & $\begin{array}{l}\text { Observations obtained } \\
\text { from zoological facilities }\end{array}$ & $\begin{array}{l}\text { Key references from } \\
\text { zoological facilities }\end{array}$ & Remaining questions \\
\hline $\begin{array}{l}\text { Social struc- } \\
\text { ture/affiliative } \\
\text { behaviour }\end{array}$ & $\begin{array}{l}\text { Reports of short-term } \\
\text { associations, shal- } \\
\text { low-water interac- } \\
\text { tions, and calf-adult } \\
\text { interactions } \\
\text { Reports that adult } \\
\text { males swim separately } \\
\text { from females during } \\
\text { part of the year }\end{array}$ & $\begin{array}{l}\text { Huntington 2005; } \\
\text { Michaud 2005; Loseto } \\
\text { et al. 2006; Cher- } \\
\text { netsky et al. 2011; } \\
\text { Krasnova et al. 2012; } \\
\text { Alekseeva et al. 2013; } \\
\text { Krasnova et al. 2014; } \\
\text { O'Corry- } \\
\text { Crowe et al. } 2020\end{array}$ & $\begin{array}{l}\text { Clear male-male asso- } \\
\text { ciations during most of } \\
\text { the year, in both adult } \\
\text { and immature belugas } \\
\text { Far fewer close associ- } \\
\text { ations in females } \\
\text { Seasonal effects }\end{array}$ & $\begin{array}{l}\text { Hill et al. 2018; } \\
\text { Mazikowski et al. 2018; } \\
\text { Ham et al. } 2021\end{array}$ & $\begin{array}{l}\text { Functional role } \\
\text { for male-male } \\
\text { associations? } \\
\text { Functional role of long- } \\
\text { term associations? }\end{array}$ \\
\hline $\begin{array}{l}\text { Tactile } \\
\text { behaviour }\end{array}$ & $\begin{array}{l}\text { Anecdotal reports of } \\
\text { occasional touching }\end{array}$ & $\begin{array}{l}\text { Alekseeva et al. 2013; } \\
\text { Krasnova et al. } 2009\end{array}$ & $\begin{array}{l}\text { Sustained observa- } \\
\text { tions of known individ- } \\
\text { uals reveal clear age } \\
\text { and sex differences }\end{array}$ & $\begin{array}{l}\text { Hill et al. 2016; Hill, } \\
\text { Dietrich et al. } 2018\end{array}$ & $\begin{array}{l}\text { Functional role of } \\
\text { touching? } \\
\text { Influence of kinship? }\end{array}$ \\
\hline $\begin{array}{l}\text { Socio-sexual } \\
\text { behaviour }\end{array}$ & $\begin{array}{l}\text { Anecdotal reports of } \\
\text { genital contact outside } \\
\text { of breeding season }\end{array}$ & $\begin{array}{l}\text { Michaud 2005; } \\
\text { Alekseeva et al. 2013; } \\
\text { Lomac-MacNair et al. } \\
2015\end{array}$ & $\begin{array}{l}\text { Identified behavioural } \\
\text { repertoire } \\
\text { Development } \\
\text { sequence from birth to } \\
\text { adulthood } \\
\text { Same sex bias }\end{array}$ & $\begin{array}{l}\text { Glabicky et al. 2010; } \\
\text { Horback et al. 2010; } \\
\text { Hill, Dietrich et al. } \\
\text { 2015; Lilley et al. } 2020\end{array}$ & $\begin{array}{l}\text { Functional role of } \\
\text { same-socio-sexual } \\
\text { contact? }\end{array}$ \\
\hline $\begin{array}{l}\text { Courtship/ } \\
\text { reproductive } \\
\text { behaviour }\end{array}$ & $\begin{array}{l}\text { Seasonality inferred } \\
\text { from the timing of } \\
\text { male-female associa- } \\
\text { tions (and from gonadal } \\
\text { measurements in } \\
\text { deceased animals) } \\
\text { Anecdotal reports of } \\
\text { fleeting male-female } \\
\text { contact }\end{array}$ & $\begin{array}{l}\text { Huntington et al. 1999; } \\
\text { Chernetsky et al. 2011; } \\
\text { Krasnova et al. 2012; } \\
\text { Alekseeva et al. 2013; } \\
\text { Lomac-MacNair et al. } \\
\text { 2015; Shelden } \\
\text { et al. } 2019\end{array}$ & $\begin{array}{l}\text { Seasonality confirmed } \\
\text { from direct observa- } \\
\text { tion of mating } \\
\text { Detailed behavioural } \\
\text { repertoire } \\
\text { Partial understanding } \\
\text { of developmental time } \\
\text { course }\end{array}$ & $\begin{array}{l}\text { Glabicky et al. 2010; } \\
\text { Hill, Dietrich et al. } \\
\text { 2015; Lilley et al. 2020; } \\
\text { Richard et al. } 2021\end{array}$ & $\begin{array}{l}\text { Sequence of courtship } \\
\text { behaviours? } \\
\text { Differential roles by } \\
\text { males and females in } \\
\text { mate choice? }\end{array}$ \\
\hline $\begin{array}{l}\text { Mother-calf } \\
\text { interactions }\end{array}$ & $\begin{array}{l}\text { Preferred habitat for } \\
\text { mother-calf pairs } \\
\text { Length of association } \\
\text { Anecdotal descriptions } \\
\text { of behaviours }\end{array}$ & $\begin{array}{l}\text { Huntington et al. 1999; } \\
\text { Mymrin et al. 1999; } \\
\text { Krasnova et al. 2003; } \\
\text { Krasnova et al. 2006; } \\
\text { Karenina et al. 2010; } \\
\text { Chernetsky etal. 2011; } \\
\text { Karenina et al. 2013; } \\
\text { Krasnova et al. 2014; } \\
\text { McGuire et al. } 2020\end{array}$ & $\begin{array}{l}\text { Behavioural } \\
\text { milestones as a } \\
\text { function of calf age } \\
\text { Specific types of } \\
\text { tactile interactions } \\
\text { Social interactions } \\
\text { outside the mother- } \\
\text { calf dyad }\end{array}$ & $\begin{array}{l}\text { Vergara \& } \\
\text { Barrett-Lennard 2008; } \\
\text { Hill 2009; Leung et al. } \\
\text { 2010; Vergara et al. } \\
\text { 2010; Hill et al. 2013; } \\
\text { Hill \& Campbell 2014; } \\
\text { Hill et al. 2016; Hill, } \\
\text { Dietrich et al. 2018; } \\
\text { Vergara \& Mikus 2019; } \\
\text { Ames \& Vergara } 2020\end{array}$ & $\begin{array}{l}\text { Length of association } \\
\text { as a function of social } \\
\text { structure? } \\
\text { Mechanism for } \\
\text { mother-calf } \\
\text { recognition? } \\
\text { Mother-calf cultural } \\
\text { transmission? } \\
\text { Long-term relationships? } \\
\text { Does intergenerational } \\
\text { maternal care occur? }\end{array}$ \\
\hline Allomothering & $\begin{array}{l}\text { Anecdotal evidence } \\
\text { reported from the } \\
\text { White Sea }\end{array}$ & Krasnova et al. 2014 & $\begin{array}{l}\text { Documented instances } \\
\text { of allocare }\end{array}$ & Hill \& Campbell 2014 & $\begin{array}{l}\text { Ascertaining whether } \\
\text { allocare occurs in the } \\
\text { wild? } \\
\text { If so, how frequently? }\end{array}$ \\
\hline
\end{tabular}


Table 1 (continued) Behavioural characteristics of beluga whales: comparison of observations obtained in the wild and observations obtained in zoological facilities.

\begin{tabular}{|c|c|c|c|c|c|}
\hline & $\begin{array}{l}\text { Observations obtained } \\
\text { from the wild }\end{array}$ & $\begin{array}{c}\text { Key references from } \\
\text { the wild }\end{array}$ & $\begin{array}{l}\text { Observations obtained } \\
\text { from zoological } \\
\text { facilities }\end{array}$ & $\begin{array}{l}\text { Key references from } \\
\text { zoological facilities }\end{array}$ & Remaining questions \\
\hline $\begin{array}{l}\text { Developmental } \\
\text { landmarks }\end{array}$ & $\begin{array}{l}\text { Swim positions } \\
\text { reported for neonates } \\
\text { and yearlings }\end{array}$ & Krasnova et al. 2006 & $\begin{array}{l}\text { Documented } \\
\text { behavioural landmarks } \\
\text { associated with age in } \\
\text { beluga calves }\end{array}$ & $\begin{array}{l}\text { Hill 2009; Hill et al. } \\
\text { 2013; Hill \& Campbell } \\
2014\end{array}$ & $\begin{array}{l}\text { Associating } \\
\text { behavioural landmarks } \\
\text { with specific ages in } \\
\text { wild populations? }\end{array}$ \\
\hline Play behaviour & $\begin{array}{l}\text { A few anecdotal } \\
\text { reports of apparent } \\
\text { play behaviour, more } \\
\text { common in immature } \\
\text { belugas, but also } \\
\text { sometimes observed } \\
\text { in adults }\end{array}$ & $\begin{array}{l}\text { Krasnova et al. 2009; } \\
\text { Krasnova et al 2012; } \\
\text { Krasnova et al 2014; } \\
\text { Alekseeva et al. } 2013\end{array}$ & $\begin{array}{l}\text { Developmental } \\
\text { progression of play } \\
\text { behaviour in calves } \\
\text { Importance of play for } \\
\text { young animals in social } \\
\text { groups } \\
\text { Variation in play } \\
\text { behaviour across } \\
\text { individuals }\end{array}$ & $\begin{array}{l}\text { Hill \& Ramirez 2014; } \\
\text { Jones \& Kuczaj 2014; } \\
\text { Hill, Guarino et al. } \\
\text { 2015; Hill et al. } 2019\end{array}$ & $\begin{array}{l}\text { Adaptive value of play } \\
\text { in natural settings? }\end{array}$ \\
\hline $\begin{array}{l}\text { Gaze direction/ } \\
\text { duration }\end{array}$ & $\begin{array}{l}\text { Anecdotal reports of } \\
\text { apparent looking at } \\
\text { novel stimuli }\end{array}$ & Karenina et al. 2010 & $\begin{array}{l}\text { Longer gazes at novel/ } \\
\text { unfamiliar stimuli }\end{array}$ & $\begin{array}{l}\text { Hill et al. 2016; Guarino } \\
\text { et al. } 2017\end{array}$ & $\begin{array}{l}\text { Adaptive value of curi- } \\
\text { osity in wild settings? }\end{array}$ \\
\hline Laterality & $\begin{array}{l}\text { Observations of } \\
\text { laterality in mother-calf } \\
\text { swim positions, and } \\
\text { in responses to novel } \\
\text { objects }\end{array}$ & $\begin{array}{l}\text { Karenina et al. 2010; } \\
\text { Karenina et al. } 2013\end{array}$ & $\begin{array}{l}\text { Similar observations of } \\
\text { lateralized orientations } \\
\text { between mothers and } \\
\text { calves } \\
\text { Lateralized responses } \\
\text { to objects and to } \\
\text { humans based on } \\
\text { familiarity }\end{array}$ & $\begin{array}{l}\text { Yeater et al. 2014; Hill, } \\
\text { Yeater et al. 2016; Hill, } \\
\text { Guarino et al. 2017; } \\
\text { Yeater et al. } 2017\end{array}$ & $\begin{array}{l}\text { Functional role of } \\
\text { laterality vis-à-vis envi- } \\
\text { ronmental and social } \\
\text { stimuli? }\end{array}$ \\
\hline $\begin{array}{l}\text { Individual } \\
\text { differences }\end{array}$ & $\begin{array}{l}\text { A few anecdotal } \\
\text { reports }\end{array}$ & $\begin{array}{l}\text { Krasnova et al. 2009; } \\
\text { Krasnova et al. 2012; } \\
\text { Krasnova et al. } 2014\end{array}$ & $\begin{array}{l}\text { Evidence of reliable } \\
\text { individual differ- } \\
\text { ences on multiple } \\
\text { measures, sugges- } \\
\text { tive of behavioural } \\
\text { syndromes }\end{array}$ & $\begin{array}{l}\text { Hill et al. 2013; Hill, } \\
\text { Guarino et al. 2015; } \\
\text { Brown 2018; Hill et al. } \\
2019\end{array}$ & $\begin{array}{l}\text { Need to develop pro- } \\
\text { cedures for following } \\
\text { individual belugas in } \\
\text { the wild? }\end{array}$ \\
\hline $\begin{array}{l}\text { Cognitive } \\
\text { processes }\end{array}$ & Nothing reported & & $\begin{array}{l}\text { Sound mimicry } \\
\text { Perception of quantity } \\
\text { Behavioural imitation }\end{array}$ & $\begin{array}{l}\text { Tsukasa et al. 2012; } \\
\text { Abramson et al. 2013; } \\
\text { Murayama et al. } 2017\end{array}$ & $\begin{array}{l}\text { Adaptive value of } \\
\text { cognitive processes in } \\
\text { the wild? }\end{array}$ \\
\hline
\end{tabular}

to inform observations made in the wild. (Table 1 provides a summary of the 12 topics reviewed above, along with key references.) To give just one example, Lomac-MacNair et al. (2015) reported summertime aerial observations over Cook Inlet of a pair of belugas making ventral-ventral contact, which Lomac-MacNair et al. interpreted as a male-female sexual event. However, aquarium-based findings (Glabicky et al.
2010) document that beluga mating behaviour is highly seasonal, male-female contact is very rare outside of season and male-male pelvic contact is quite common during the summer, making it much more likely that the observation reported by Lomac-MacNair et al. (2015) was an instance of male-male socio-sexual contact. This illustrates how lengthy observations of captive animals may illuminate much briefer 
observations made on wild animals and demonstrates how information gained in the two settings might combine to direct future research.

While captive facilities continue to implement modifications in structure, social groupings and enrichment that allow for more and more natural behaviour, it must be recognized that captive animals inevitably face behavioural restrictions, particularly for large-scale behaviours, such as long-distance movements and foraging. Studies in the wild will always be the primary means by which information is obtained about animals moving freely.

Nevertheless, it is argued here that the more specific knowledge gained from aquarium-based research can guide future behavioural observations in the wild. The study of individual differences is an example. Not only does this topic have clear relevance for the survival and reproductive fitness of many animals (Smith $\&$ Blumstein 2008; Sargeant \& Mann 2009), knowledge of individual characteristics has also implications for social grouping management and reproductive compatibility both in the wild and in zoological facilities (Highfill \& Kuczaj 2007, 2010; Frick et al. 2017). Measurable behaviours, operational definitions, rating scales and tests of various components of personality (e.g., neophobia, curiosity) are outcomes of captive-based research that could inform research on wild belugas.

It should also be emphasized that the reverse should also be true. It is critically important that captive facilities keep abreast of advances in understanding the ecology of the animals that are in managed care. As more and more research is conducted on the social compositions and social interactions of wild belugas, the resulting knowledge will be useful for informing decisions made by managers of belugas in aquarium settings. Over the last 10 years, zoological facilities have strived to maintain groupings that increasingly match the social structures seen in belugas in their natural habitat: male-only groups, mothers and their calves, adult females with some adult males, and a mixed age and sex social grouping.

It is hoped that wild-based and aquarium-based studies will increasingly be mutually informative, moving towards a collaborative synergy that takes advantage of the strengths of each setting to promote beluga conservation in the wild and better welfare in captivity.

\section{Acknowledgements}

The authors gratefully acknowledge the hospitality of Georgia Aquarium, Marineland of Canada, Mystic Aquarium, Sea World San Antonio, Sea World San Diego and Shedd Aquarium for their support of the ongoing research by the authors. They also thank to Jackson Ham and Malin Lilley, who provided helpful reviews of an early manuscript.

\section{Disclosure statement}

The authors report no conflict of interest.

\section{Funding}

No financial support was received for the conduct of the research reported here. Mystic Aquarium provided the fees for publication in the journal Polar Research.

\section{References}

Abramson J.Z., Hernández-Lloreda V., Call J. \& Colmenares F. 2013. Relative quantity judgments in the beluga whale (Delphinapterus leucas) and the bottlenose dolphin (Tursiops truncatus). Behavioural Processes 96, 11-19, doi: 10.1016/j. beproc.2013.02.006.

Alekseeva Y.I., Panova E.M. \& Bel'kovich V.M. 2013. Behavioral and acoustical characteristics of the reproductive gathering of beluga whales (Delphinapterus leucas) in the vicinity of Myagostrov, Golyi Sosnovets, and Roganka Islands (Onega Bay, the White Sea). Biology Bulletin 40, 307-317, doi: 10.1134/S1062359013030023.

Ames A.E. \& Vergara V. 2020. Trajectories of vocal repertoire development in beluga (Delphinapterus leucas) calves: insights from studies a decade apart. Aquatic Mammals 46, 344-366, doi: 10.1578/AM.46.4.2020.344.

Bailey N.W. \& Zuk M. 2009. Same-sex sexual behavior and evolution. Trends in Ecology $\theta$ Evolution 24, 439-446, doi: 10.1016/j.tree.2009.03.014.

Baillargeon R., Scott R.M., He Z., Sloane S., Setoh P., Jin K.-S., Wu D. \& Bian L. 2015. Psychological and sociomoral reasoning in infancy. In M. Mikulincer et al. (eds.): APA handbook of personality and social psychology. Vol. 1. Attitudes and social cognition. Pp. 79-150. Washington, DC: American Psychological Association.

Boltunov A.N. \& Belikov S.E. 2002. Belugas (Delphinapterus leucas) of the Barents, Kara and Laptev seas. NAMMCO Scientific Publications 4, 149-168, doi: 10.7557/3.2842.

Brodie P.F. 1971. A reconsideration of aspects of growth, reproduction, and behavior of the white whale (Delphinapterus leucas), with reference to the Cumberland Sound, Baffin Island, population. Journal of the Fisheries Board of Canada 28, 1309-1318, doi: 10.1139/f71-198.

Brown B. 2018. Exploring temperament in beluga whale calves (Delphinapterus leucas). PhD thesis, University of Southern Mississippi.

Chernetsky A.D., Krasnova V.V. \& Bel'kovich V.M. 2011. Studies of the structure of the Solovetsky reproductive gathering of beluga whales (Delphinapterus leucas) in the White Sea using the photo identification method. Oceanology 51, 275-280, doi: 10.1134/S0001437011020044. 
Colbeck G.J., Duchesne P., Postma L.D., Lesage V., Hammill M.O. \& Turgeon J. 2013. Groups of related belugas (Delphinapterus leucas) travel together during their seasonal migrations in and around Hudson Bay. Proceedings of the Royal Society Biology 280, 2552-2561, doi: 10.1098/rspb.2012.2552.

Connor R.C. \& Krützen M. 2015. Male dolphin alliances in Shark Bay: changing perspectives in a 30-year study. Animal Behaviour 103, 223-235, doi: 10.1016/j. anbehav.2015.02.019.

DiPaola S., Akai C. \& Kraus B. 2007. Experiencing belugas: action selection for an interactive aquarium exhibit. Adaptive Behavior 15, 99-113, doi: 10.1177/1059712306076251.

Dudzinski K., Gregg J., Paulos R.D. \& Kuczaj S.A. 2010. A comparison of pectoral fin contact for three distinct dolphin populations. Behavioural Processes 84, 559-567, doi: 10.1016/j.beproc.2010.02.013.

Dudzinski K., Gregg J., Ribic C. \& Kuczaj S. 2009. A comparison of pectoral fin contact between two different wild dolphin populations. Behavioural Processes 80, 182-190, doi: 10.1016/j.beproc.2008.11.011.

Dudzinski K.M. \& Ribic C.A. 2017. Pectoral fin contact as a mechanism for social bonding among dolphins. Animal Behavior and Cognition 4, 30-48, doi: 10.12966/ abc.03.02.2017.

Frick E.E., de Vere A.J. \& Kuczaj S.A. 2017. What do we want to know about personality in marine mammals? In J. Vonk et al. (eds.): Personality in nonhuman animals. Pp. 237-253. Cham, Switzerland: Springer.

Furuichi T., Connor R. \& Hashimoto C. 2014. Non-conceptive sexual interactions in monkeys, apes, and dolphins. In J. Yamagiwa \& L. Karczmarski (eds.): Primates and cetaceans. Pp. 385-408. Tokyo: Springer.

Glabicky N., DuBrava A. \& Noonan M. 2010. Social-sexual behavior seasonality in captive beluga whales (Delphinapterus leucas). Polar Biology 33, 1145-1147, doi: 10.1007/s00300-010-0790-3.

Godde S., Humbert L., Côté S.D., Réale D. \& Whitehead H. 2013. Correcting for the impact of gregariousness in social network analyses. Animal Behaviour 85, 553-558, doi: 10.1016/j.anbehav.2012.12.010.

Goertz C.E., Burek-Huntington K., Royer K., Quakenbush L., Clauss T., Hobbs R. \& Kellar N.M. 2019. Comparing progesterone in blubber and serum to assess pregnancy in wild beluga whales (Delphinapterus leucas). Conservation Physiology 7 , article no. coz071, doi: 10.1093/conphys/coz071.

Guarino S., Yeater D., Lacy S., Dees T. \& Hill H. 2017. Responses to familiar and unfamiliar objects by belugas (Delphinapterus leucas), bottlenose dolphins (Tursiops truncatus), and Pacific white-sided dolphins (Lagenorhynchus obliquidens). Animal Cognition 20, 823-827, doi: 10.1007/s10071-017-1103-9.

Ham J.R., Lilley M.K. \& Manitzas Hill H.M. 2021. Seasonality of social behaviour among immature belugas (Delphinapterus leucas) in managed care. Polar Research 40, article no. 5498, doi: 10.33265/polar.v40.5498

Heide-Jørgensen M.P. \& Teilmann J. 1994. Growth, reproduction, age structure and feeding habits of white whales (Delphinapterus leucas) in west Greenland waters. Meddelelser om Grønland Bioscience 39, 195-212.
Highfill L.E. \& Kuczaj S.A. 2007. Do bottlenose dolphins (Tursiops truncatus) have distinct and stable personalities? Aquatic Mammals 33, 380-389, doi: 10.1578/ AM.33.3.2007.387.

Highfill L.E. \& Kuczaj S.A. 2010. How studies of wild and captive dolphins contribute to our understanding of individual differences and personality. International Journal of Comparative Psychology 23, 269-277.

Hill H. 2009. The behavioral development of two beluga calves during the first year of life. International Journal of Comparative Psychology 22, 234-253.

Hill H., Alvarez C., Dietrich S. \& Lacy K. 2016. Preliminary findings in beluga (Delphinapterus leucas) tactile interactions. Aquatic Mammals 42, 277-291, doi: 10.1578/ AM.42.3.2016.277.

Hill H. \& Campbell C. 2014. Allocare depends on social composition for belugas (Delphinapterus leucas) in human care. International Journal of Comparative Psychology 27, 501-514, doi: 10.46867/ijcp.2014.27.04.08.

Hill H., Campbell C., Dalton L. \& Osborn S. 2013. The first year of behavioral development and maternal care of beluga (Delphinapterus leucas) calves in human care. Zoo Biology 32, 565-570, doi: 10.1002/zoo.21093.

Hill H., Dietrich S., Finn R., Garza S., Alvarez C., Lacy K. \& Kuczaj S. 2018. Role of contact in beluga (Delphinapterus leucas) calf relationships. Aquatic Mammals 44, 62-75, doi: 10.1578/AM.44.1.2018.62.

Hill H., Dietrich S., Yeater D., McKinnon M., Miller M., Aibel S. \& Dove A. 2015. Developing a catalog of sexual and socio-sexual behaviors of beluga whales in the care of humans. Animal Behavior and Cognition 2, 105-123, doi: 10.12966/abc.05.01.2015.

Hill H., Guarino S., Crandall S., Lenhart E. \& Dietrich S. 2015. Young belugas diversify adult beluga (Delphinapterus leucas) behavior. Animal Behavior and Cognition 2, 267-284, doi: 10.12966/abc.08.06.2015.

Hill H. \& Ramirez D. 2014. Adults play but not like their young: the frequency and types of play by belugas (Delphinapterus leucas) in human care. Animal Behavior and Cognition 1, 166-185, doi: 10.12966/abc.05.07.2014.

Hill H.M., Dietrich S. \& Cappiello B. 2017. Learning to play: a review and theoretical investigation of the developmental mechanisms and functions of cetacean play. Learning O Behavior 45, 335-354, doi: 10.3758/s13420-017-0291-0.

Hill H.M., Dietrich S., Guarino S., Banda M. \& Lacy K. 2019. Preliminary observations of an unusual mouth interaction between beluga calves (Delphinapterus leucas). Zoo Biology 38, 149-156, doi: 10.1002/zoo.21463.

Hill H.M., Garcia de Oliveira Silva-Gruber D. \& Noonan M. 2018. Sex-specific social affiliation in captive beluga whales (Delphinapterus leucas). Aquatic Mammals 44, 250-255, doi: 10.1578/AM.44.3.2018.250.

Hill H.M., Guarino S., Calvillo A., Gonzalez A., Zuniga K., Bellows C., Polasek L. \& Sims C. 2017. Lateralized swim positions are conserved across environments for beluga (Delphinapterus leucas) mother-calf pairs. Behavioural Processes 138, 22-28, doi: 10.1016/j.beproc.2017.01.018.

Hill H.M., Woodruff M.J. \& Noonan M. 2019. Individual differences in the behavioral characteristics of beluga whales 
(Delphinapterus leucas). Behavioural Processes 166, article no. 103885, doi: 10.1016/j.beproc.2019.06.008.

Hill H.M., Yeater D., Gallup S., Guarino S., Lacy S., Dees T. \& Kuczaj S. 2016. Responses to familiar and unfamiliar humans by belugas (Delphinapterus leucas), bottlenose dolphins (Tursiops truncatus), \& Pacific white-sided dolphins (Lagenorhynchus obliquidens): a replication and extension. International Journal of Comparative Psychology 29, article no. 32012.

Horback K.M., Friedman W.R. \& Johnson C.M. 2010. The occurrence and context of s-posture display by captive belugas (Delphinapterus leucas). International Journal of Comparative Psychology 23, 689-700.

Huntington H.P. 2005. "We dance around in a ring and suppose": academic engagement with Traditional Knowledge. Arctic Anthropology 42, 29-32, doi: 10.1353/ arc.2011.0101.

Huntington H.P. \& Communities of Buckland, Elim, Koyuk, Point Lay and Shaktoolik 1999. Traditional Knowledge of the ecology of beluga whales (Delphinapterus leucas) in the eastern Chukchi and northern Bering seas, Alaska. Arctic 52, 49-61, doi: 10.14430/arctic909.

Jones B.L. \& Kuczaj S.A. 2014. Beluga (Delphinapterus leucas) novel bubble helix play behavior. Animal Behavior and Cognition 1, 206-214, doi: 10.12966/abc.05.10.2014.

Karenina K., Giljov A., Baranov V., Osipova L., Krasnova V. \& Malashichev Y. 2010. Visual laterality of calf-mother interactions in wild whales. PLoS One 5, e13787, doi: 10.1371/ journal.pone.0013787.

Karenina K., Giljov A., Glazov D. \& Malashichev Y. 2013. Social laterality in wild beluga whale infants: comparisons between locations, escort conditions, and ages. Behavioral Ecology and Sociobiology 67, 1195-1204, doi: 10.1007/s00265-013-1545-2.

Krasnova V., Belkovich V. \& Chernetsky A. 2003. Dynamics of belugas (Delphinapterus leucas) behavior in reproduction gathering. In P.G.H. Evans et al. (eds.): Proceedings of the Seventeenth Annual Conference of the European Cetacean society, Las Palmas de Gran Canaria, Canary Islands, Spain, 9-13 March 2002. Pp. 130-139. European Cetacean Society.

Krasnova V.V., Bel'kovich V.M. \& Chernetsky A.D. 2006. Mother-infant spatial relations in wild beluga (Delphinapterus leucas) during postnatal development under natural conditions. Biology Bulletin 33, 53-58, doi: 10.1134/S1062359006010079.

Krasnova V.V., Bel'kovich V.M. \& Chernetsky A.D. 2009. Formation of behavior in the White Sea beluga calf, Delphinapterus leucas, during early postnatal ontogenesis. Russian Journal of Marine Biology 35, 53-59, doi: 10.1134/ S1063074009010088.

Krasnova V.V., Chernetsky A.D., Kirillova O.I. \& Bel'kovich V.M. 2012. The dynamics of the abundance, age, and sex structure of the Solovetsky reproductive gathering of the beluga whale Delphinapterus leucas (Onega Bay, White Sea). Russian Journal of Marine Biology 38, 218-225, doi: 10.1134/S1063074012030078.

Krasnova V.V., Chernetsky A.D., Zheludkova A.I. \& Bel'kovich V.M. 2014. Parental behavior of the beluga whale (Delphinapterus leucas) in natural environment. Biology Bulletin 41, 349-356, doi: 10.1134/ S1062359014040062.
Kuczaj S.A., Makecha R., Trone M., Paulos R.D. \& Ramos J.A. 2006. Role of peers in cultural innovation and cultural transmission: evidence from the play of dolphin calves. International Journal of Comparative Psychology 19, 223-240.

Leung E.S., Vergara V. \& Barrett-Lennard L.G. 2010. Allonursing in captive belugas (Delphinapterus leucas). Zoo Biology 29, 633-637, doi: 10.1002/zoo.20295.

Lilley M.K., Ham J.R. \& Hill H.M. 2020. The development of socio-sexual behavior in belugas (Delphinapterus leucas) under human care. Behavioural Processes 171, article no. 104025, doi: 10.1016/j.beproc.2019.104025.

Lomac-MacNair K.S., Smultea M.A., Cotter, M.P., Thissen C. \& Parker L. 2015. Socio-sexual and probable mating behavior of Cook Inlet beluga whales, Delphinapterus leucas, observed from an aircraft. Marine Fisheries Review 77, 32-39, doi: 10.7755/MFR.77.2.2.

Loseto L.L., Richard P., Stern G.A., Orr J. \& Ferguson S.H. 2006. Segregation of Beaufort Sea beluga whales during the open-water season. Canadian Journal of Zoology 84, 1743-1751, doi: 10.1139/z06-160.

Mann J. 2006. Male-male bonds among Indian Ocean bottlenose dolphins. In V. Sommer \& P.L. Vasey (eds.): Homosexual behaviour in animals: an evolutionary perspective. Pp. 107-130. Cambridge: Cambridge University Press.

May-Collado L.J., Agnarsson I. \& Wartzok D. 2007. Phylogenetic review of tonal sound production in whales in relation to sociality. BMC Evolutionary Biology 7, article no. 136, doi: 10.1186/1471-2148-7-136.

Mazikowski L., Hill H. \& Noonan M. 2018. Juvenile belugas (Delphinapterus leucas) exhibit sex-specific social affiliations. Aquatic Mammals 44, 500-505, doi: 10.1578/ AM.44.5.2018.500.

McGuire T.L., Himes Boor G.K., McClung J.R., Stephens A.D., Garner C., Shelden K.E. \& Wright, B. 2020. Distribution and habitat use by endangered Cook Inlet beluga whales: patterns observed during a photo-identification study, 2005-2017. Aquatic Conservation: Marine and Freshwater Ecosystems 30, 2402-2427, doi: 10.1002/aqc.3378.

Michaud R. 2005. Sociality and ecology of the odontocetes. In K. Ruckstuhl \& P. Neuhaus (eds.): Sexual segregation in vertebrates: ecology of the two sexes. Pp. 303-326. Cambridge: Cambridge University.

Murayama T., Suzuki R., Kondo Y., Koshikawa M., Katsumata H. \& Arai K. 2017. Spontaneous establishing of cross-modal stimulus equivalence in a beluga whale. Scientific Reports 7, article no. 9914, doi: 10.1038/ s41598-017-09925-4.

Mymrin N.I., Communities of Novoe Chaplino, Sireniki, Uelen, and Yanrakinnot \& Huntington H.P. 1999. Traditional Knowledge of the ecology of beluga whales (Delphinapterus leucas) in the northern Bering Sea, Chukotka, Russia. Arctic 52, 62-70, doi: 10.14430/arctic910.

O'Corry-Crowe G., Suydam R., Quakenbush L., Smith T.G., Lydersen C., Kovacs K.M., Orr J., Harwood L., Litovka D. \& Ferrer T. 2020. Group structure and kinship in beluga whale societies. Scientific Reports 10, article no. 11462, doi: 10.1038/s41598-020-67314-w.

O'Corry-Crowe G.M., Suydam R.S., Rosenberg A., Frost K.J. \& Dizon A.E. 1997. Phylogeography, population 
structure and dispersal patterns of the beluga whale Delphinapterus leucas in the western Nearctic revealed by mitochondrial DNA. Molecular Ecology 6, 955-970, doi: 10.1046/j.1365-294X.1997.00267.x.

Paulos R.D., Trone M. \& Kuczaj S.A. II. 2010. Play in wild and captive cetaceans. International Journal of Comparative Psychology 23, 701-722.

Recchia C.A. 1994. Social behaviour of captive belugas, Delphinapterus leucas. PhD thesis, Woods Hole Oceanographic Institution.

Richard J., Romano T. \& Sartini B. 2021 . Minimally invasive physiological correlates of social behaviour in belugas (Delphinapterus leucas) under human care. Polar Research 40, article no. 5504, doi: 10.33265/polar.v40.5504.

Richard P.R., Heide-Jørgensen M.P., Orr J.R., Dietz R. \& Smith T.G. 2001. Summer and autumn movements and habitat use by belugas in the Canadian High Arctic and adjacent areas. Arctic 54, 207-222, doi: 10.14430/arctic782.

Robeck T.R., Monfort S.L., Calle P.P., Dunn J.L., Jensen E., Boehm J.R., Young S. \& Clark S.T. 2005. Reproduction, growth and development in captive beluga (Delphinapterus leucas). Zoo Biology 24, 29-49, doi: 10.1002/zoo.20037.

Sargeant B.L. \& Mann J. 2009. Developmental evidence for foraging traditions in wild bottlenose dolphins. Animal Behaviour 78, 715-721, doi: 10.1016/j.anbehav.2009.05.037.

Sergeant D.E. 1973. Biology of white whales (Delphinapterus leucas) in western Hudson Bay. Journal of the Fisheries Board of Canada 30, 1065-1090, doi: 10.1139/f73-178.

Shelden K.E., Robeck T.R., Goertz C.E., McGuire T.L., Burek-Huntington K.A., Vos D.J. \& Mahoney B.A. 2019. Breeding and calving seasonality in the endangered Cook Inlet beluga whale population: application of captive fetal growth curves to fetuses and newborns in the wild. Marine Mammal Science 36, 700-708, doi: 10.1111/mms.12653.

Siniscalchi M., Dimatteo S., Pepe A.M., Sasso R. \& Quaranta A. 2012. Visual lateralization in wild striped dolphins (Stenella coeruleoalba) in response to stimuli with different degrees of familiarity. PLoS One 7, e30001, doi: 10.1371/ journal.pone.0030001

Skrzypczak N. 2016. Personality traits in the Atlantic spotted dolphin (Stenella frontalis): syndromes and predictors of neophilia. MSc thesis, Florida Atlantic University.

Smith B.R. \& Blumstein D.T. 2008. Fitness consequences of personality: a meta-analysis. Behavioral Ecology 19, 448-455, doi: 10.1093/beheco/arm 144.
Tamaki N., Morisaka T. \& Taki M. 2006. Does body contact contribute towards repairing relationships? The association between flipper-rubbing and aggressive behavior in captive bottlenose dolphins. Behavioural Processes 73, 209-215, doi: 10.1016/j.beproc.2006.05.010.

Themelin M., Ribic C.A., Melillo-Sweeting K. \& Dudzinski K.M. 2020. A new approach to the study of relationship quality in dolphins: framework and preliminary results. Behavioural Processes 181, article no. 104260, doi: 10.1016/j. beproc.2020.104260.

Tsukasa M., Fujii Y., Hashimoto T., Shimoda A., Iijima S., Hayasaka K. Shiroma N., Koshikawa M., Katsumata H., Soichi M. \& Arai K. 2012. Preliminary study of object labeling using sound production in a beluga. International Journal of Comparative Psychology 25, 195-207.

Vasey P.L. 1995. Homosexual behavior in primates: a review of evidence and theory. International Journal of Primatology 16, 173-204, doi: 10.1007/BF02735477.

Vergara V. \& Barrett-Lennard L.G. 2008. Vocal development in a beluga calf (Delphinapterus leucas). Aquatic Mammals 34, 123-143, doi: 10.1578/AM.34.1.2008.123.

Vergara V., Michaud R. \& Barrett-Lennard L. 2010. What can captive whales tell us about their wild counterparts? Identification, usage, and ontogeny of contact calls in belugas (Delphinapterus leucas). International Journal of Comparative Psychology 23, 278-309.

Vergara V. \& Mikus M.A. 2019. Contact call diversity in natural beluga entrapments in an Arctic estuary: preliminary evidence of vocal signatures in wild belugas. Marine Mammal Science 35, 434-465, doi: 10.1111/ mms. 12538.

Yeater D., Guarino S., Lacy S., Dees T. \& Hill H. 2017. Do belugas (Delphinapterus leucas), bottlenose dolphins (Tursiops truncatus), \& Pacific white-sided dolphins (Lagenorhynchus obliquidens) display lateralized eye preference when presented with familiar or novel objects? International Journal of Comparative Psychology 30, article no. 35458, doi: 10.46867/ijcp.2017.30.00.02.

Yeater D., Hill H., Baus N., Farnell H. \& Kuczaj S. 2014. Visual laterality in belugas (Delphinapterus leucas) and Pacific white-sided dolphins (Lagenorhynchus obliquidens) when viewing familiar and unfamiliar humans. Animal Cognition 17, 1245-1259, doi: 10.1007/ s10071-014-0756-x. 